This item was submitted to Loughborough's Research Repository by the author.

Items in Figshare are protected by copyright, with all rights reserved, unless otherwise indicated.

\title{
The mirror of anarchy: the egoism of John Henry Mackay and Dora Marsden
}

PLEASE CITE THE PUBLISHED VERSION

http://www.palgrave.com/products/title.aspx?pid=483235

\section{PUBLISHER}

(c) Palgrave Macmillan

\section{VERSION}

SMUR (Submitted Manuscript Under Review)

\section{LICENCE}

CC BY-NC-ND 4.0

\section{REPOSITORY RECORD}

Kinna, Ruth. 2019. "The Mirror of Anarchy: The Egoism of John Henry Mackay and Dora Marsden". figshare. https://hdl.handle.net/2134/9153. 
This item was submitted to Loughborough's Institutional Repository (https://dspace.lboro.ac.uk/) by the author and is made available under the following Creative Commons Licence conditions.

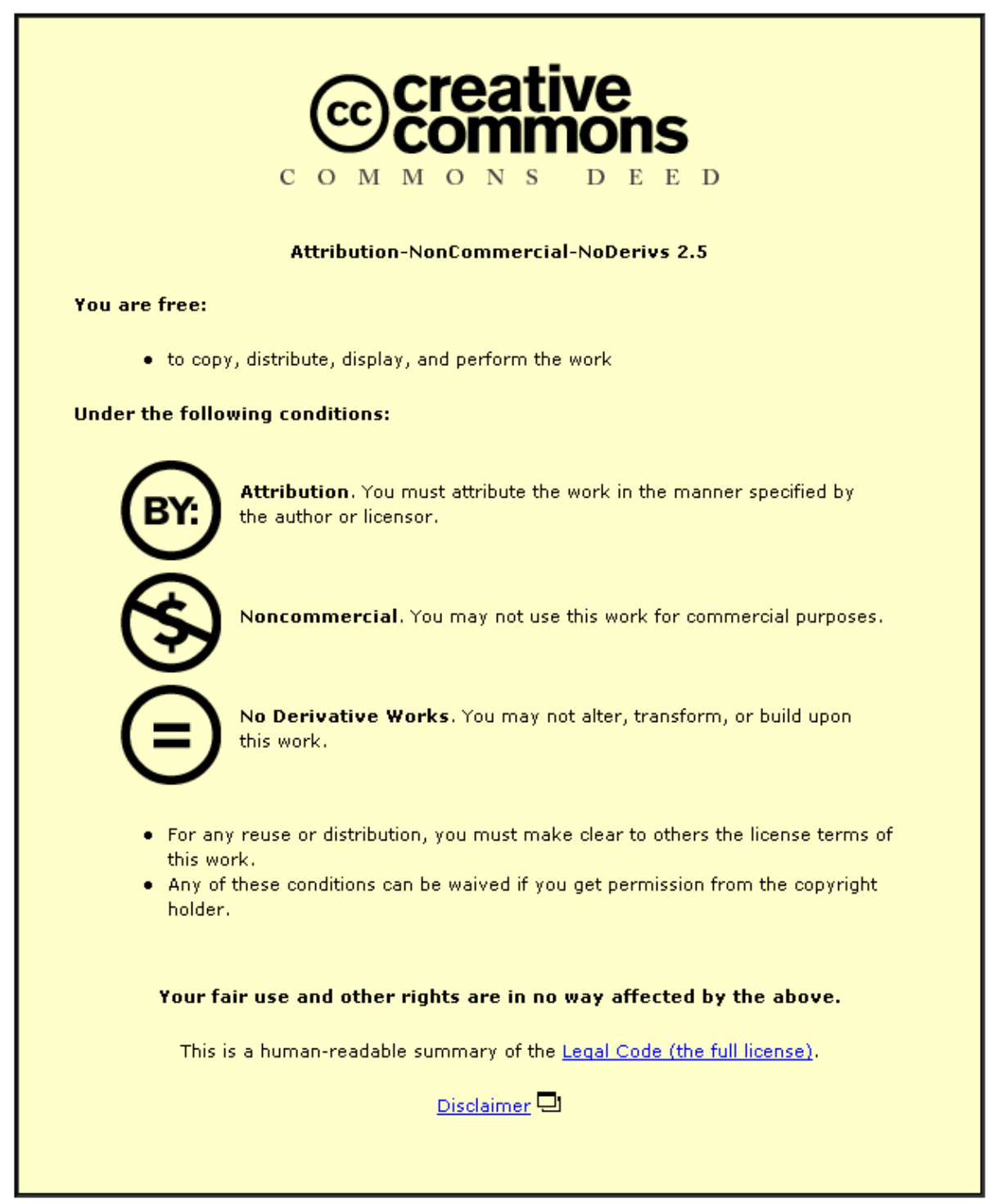

For the full text of this licence, please go to: http://creativecommons.org/licenses/by-nc-nd/2.5/ 
The Mirror of Anarchy: The egoism of John Henry Mackay and Dora Marsden ${ }^{1}$

\section{Ruth Kinna}

\section{$\underline{\text { Introduction }}$}

Stirner occupies a curious place in the history of anarchist ideas. Although he has been identified as a central figure in histories of anarchist thought, he is probably the least celebrated of the nineteenth-century thinkers. Disquiet about Stirner's place in the canon was apparent as early as the 1880 s and ' 90 s, the period of Stirner's revival. Although important figures like Max Nettlau attempted to negotiate the differences between individualists and communists, Kropotkin and Malatesta both advanced strong criticisms of growing egoist trends. ${ }^{2}$ Even writers who admired Nietzsche, with whom Stirner's work was frequently associated in anarchist circles, were prone to attack Stirner. In review for Mother Earth Max Baginski, dismissed the celebration of his work a 'harmless bourgeois cult' and compared it unfavourably to Nietzshe's. ${ }^{3}$ It is perhaps symbolic of the awkwardness anarchists felt about Stirner's contribution that no drawing of him appeared on the cover of the Freedom edition of Paul Eltzbacher's study of the seven sages: uniquely his name is set in the frame of a blank box.

As the black sheep of anarchism, Stirner has sometimes been used as a cipher in ideological polemics. He remains a favourite subject of anti-anarchist critique, still used by Marxists to illustrate the destructive individualism said to lie at the heart of anarchist thought. ${ }^{4}$ Voices aligned to class-struggle anarchism have similarly recruited Stirner in their battles to drive a wedge between anarcho-communist and individualist positions. In his defence of platformism, Alexandre Skirda links egoism to illegalism with some justification, but also, and less justifiably, to intellectual bankruptcy and 
personal and strategic failure. ${ }^{5}$ Michael Schmidt and Lucien van der Walt argue that Stirner was anti-socialist and anti-revolutionary. They place him outside the 'broad anarchist tradition'. ${ }^{6}$ Contemporary scholars who have given sustained attention to Stirner's political thought have been kinder to him. Nevertheless, Stirner continues to be used to as a mirror to reflect on the shortcomings of anarchism. Saul Newman's analysis of Stirner appears, at least in part, to have been driven by a desire to illustrate the shortcomings of anarchism. Rather than raising a critique of Stirner's work to reflect on anarchism, he instead mounts a defence.

The strangeness of the place Stirner occupies as the reprobate architect of anarchist thought is matched by the consensus about his individualism. Interestingly, since he defends Stirner, Newman sketches the grounds of class-struggle anarchist concerns when he comments on Stirner's 'extreme individualism and egoism'. This extremism, he argues, amounted to a tendency to treat any 'collective identity' as 'an oppressive burden', a position which leaves little room 'to theorize a collective politics of resistance'. Stirner talked about the 'Unity of Egos', but Newman hints that his politics might be 'limited to individual rebellion'. ${ }^{7}$ Some scholars have suggested that such assessments of Stirner are mistaken and that they stem from a fundamental misunderstanding of nineteenth-century traditions. Allan Antliff's work on modernism shows that the creative impulse that Newman associates with Stirnerite autonomy had a central place in anarcho-communist thought and that ideas now attributed to Stirner were common currency in early twentieth-century anarchist movements and well-embedded in so-called classical traditions. ${ }^{8}$ Antliff's fire is directed towards Newman, but insofar as it identifies a misrepresentation, it has equal application to anti-individualist critiques. 
The correspondence of Newman's critical assessment of egoism with antiindividualist class struggle anarchism is puzzling and, as Antliff's work indicates, points to the possibility of an interrelationship in communist and individualist traditions that both parties to the debate are keen to resist. To consider this possibility and the parameters of the individualist-communist divide, I follow Newman in treating Stirnerism as a mirror through which to reflect on anarchism. However, whereas Newman presents an analysis of Stirner's work to abstract a critique of anarchism, I develop a model of Stirnerism from late nineteenth and early twentiethcentury sources and show how egoist critique reflects on this model. The picture of Stirnerism it paints is quite different from the one Newman finds and more porous to the sorts of exchanges Antliff identifies. The paper begins with an account of Newman's defence and then proceeds to a discussion of J.H. Mackay and Dora Marsden.

\section{Newman: Stirner and anarchism}

The idea which emerges most forcefully from Saul Newman's defence of Stirner is difference. Stirner's work, he argues, attacked the liberal idea that 'every kind of particularity and difference must be overcome'. ${ }^{9}$ Stirner showed that liberalism involves the "progressive "taming" of the individuals - a restriction of his difference and singularity'. ${ }^{10} \mathrm{He}$ argued, rightly, that 'individuals who deviate from the accepted moral and rational norms of liberalism are excluded from the liberal polity'. Worse, that in liberalism 'the individual himself is split between an identification with liberal subjectivity, and a recognition of those elements of himself which do not or cannot confirm to this ideal'. ${ }^{11}$ Individuals are expected to 'conform to a certain rational 
mode of freedom', based on 'a false universality and neutrality which masks its complicity with power': ${ }^{12}$

Freedom and autonomy are conditional upon the individual conforming to an abstract generality, therefore denying his difference and individuality. Those who do not or cannot live up to this ideal are excluded, marginalized and subjected to a whole series of regulatory, judicial, medical and disciplinary procedures which have as their aim the normalization of the individual. Stirner may therefore be seen as a crucial link in the post-Enlightenment and poststructuralist critique of liberalism - particularity his questioning of the conditions under which the liberal subject is constituted. ${ }^{13}$

Whilst the thrust of Stirner's critique seems to be anti-liberal, Newman finds its normative promise in what he calls its "'hyper-liberalism"”. Stirner's response to restrictive liberalism was to explode its boundaries. He saw individuality as 'a radical excess ... something that spills over its edges and jeopardizes [liberalism's] limits. ${ }^{14}$ It was up to each individual, therefore, 'go beyond the formal freedoms of liberalism and invent his own forms of autonomy'. Liberals, Newman argues, must acknowledge that rights and freedoms are not founded on 'some universal, essential subjectivity, but on a series of arbitrary exclusions, discursive constructions and strategies of power'. ${ }^{15}$ They must, then, abandon the search for 'a universal epistemological standpoint - to find the best form of life from which others can be judged'. Newman's attack is directed against Rawlsians and it leads him to embrace John Gray's 'agonistic liberalism'. Rather than 'search for a rational consensus about the "best life", he argues, we should recognise the "incommensurability of different 
perspectives in modern society'. ${ }^{16}$ This form of radical pluralism acknowledges the 'irreducibility of difference' and the establishment of 'a modus vivendi between competing forms of life'. ${ }^{17}$ In a practical sense, it does not lead to an abandonment of formal rights and freedoms but their extension to groups and identities that liberalism - in the name of universality - currently excludes.

Whilst Newman uses this analysis of Stirner to attack Rawlsian liberalism, the critique is also relevant to traditional forms of socialism, including anarchism. The argument rests on Stirner's characterisation of enlightenment thinking which, as Newman acknowledges, emerges through his critique of Feuerbach. To show how Stirner breaks with the tradition of enlightenment Humanism, he outlines three movements of a counter-dialectic presented in Stirner's classic work, The Ego and Its Own. ${ }^{18}$ The first phase is marked by the emergence of 'political liberalism' and the claim for formal equality of rights. For Stirner, Newman argues, this involves the construction of a 'general anonymous political identity ... - the citizen'- and rather than giving individuals autonomy from the state, it binds them to it. ${ }^{19}$ The second movement, 'social liberalism', demands the extension of political rights to the social and economic sphere and is associated with the socialist demand for the abolition of property rights. Newman argues: 'behind this discourse of social and economic equality for all, there is a pernicious and hidden resentment of individual difference'. ${ }^{20}$ On Stirner's account, social liberalism is only a demand for levelling. ${ }^{21}$ The final phase of the dialectic - 'humane liberalism' - overcomes the contradiction between the drive for autonomy that Stirner locates in property or 'ownness' and the demand for economic equality by imposing a duty to subordinate self-interest to the common good. The goal of the humane liberal is to achieve a 'state of perfection and harmony' and the cost is that all individual differences are finally transcended. ${ }^{22}$ 
Even though it rejected the state, Newman argues that anarchism was fully immersed in this humane-enlightenment tradition. Instead of thinking of individuals as right-bearers, anarchists cast them as essentially rational, and sociable. These essential characteristics encouraged the anarchists to parallel Stirner's counterdialectic with a utopian vision framed by a rejection of liberalism. Taking issue with the claims that political liberals advanced about the citizen, the anarchists argued that freedom lay in state's abolition. Yet accepting the humane liberal position, anarchists argued that the condition for this liberation lay in the achievement of social and economic equality. Where political liberals saw the ethical state as the vehicle through which the tensions between individual and society could be resolved, the anarchists identified the social, cultural, religious and economic inequalities that the state upheld as the cause of artificial division between naturally co-operative social beings. The conditions for harmony were entirely opposite, but the ideal was the same. Anarchists and liberals shared a singular conception of humankind and both were equally intolerant of individual difference.

Newman's argument has been powerfully persuasive, but as Antliff argues, the claim that the critique accurately captures a dominant anarchist view is dubious. In distancing themselves from egoism, oppositional anarchists did not thereby endorse the positions Stirner associated with enlightenment humanism. Indeed, it is not even clear that the terms of debate were framed in the way that Newman suggests. To consider how they were framed, I turn to the work of two of Stirner's leading advocates, John Henry Mackay and Dora Marsden. 


\section{Stirnerism at the turn of the twentieth century}

John Henry MacKay (1864-1933) and Dora Marsden (1882-1960) are both excellent guides to turn-of-the-century Stirnerism. MacKay was a writer and poet who actively campaigned for homosexual rights and the abolition of the age of consent. Using the pseudonym 'Sagitta' he wrote a number of books to encourage acceptance of intergenerational sex or 'man-boy love'. Of these, The Hustler was the most clearly propagandistic and written from an overtly anarchist perspective. ${ }^{23}$ However, he is probably better known as the author of The Anarchists, a fictionalised account of his experiences in the London anarchist movement in 1887-8. This book was written before Mackay became acquainted with Stirner's writings, but its success helped seal his reputation as a leading interpreter of Stirner's thought. Subsequently recognising the coincidence of views, Mackay became a keen advocate of Stirner's work and set about collecting his papers. When Richard Strauss first thought about setting some of MacKay's poetry to music in the 1890 s, he described him as the 'great anarchist and biographer of the Berlin philosopher Max Stirner' ${ }^{24}$ Kropotkin also credited him with bringing Stirner into prominence, ${ }^{25}$ a claim Mackay endorsed: 'What would one know of today of Max Stirner and his life without me?' he asked. His answer:

'"Nothing!"’.26

Like MacKay, Dora Marsden had already moved toward egoism before she read Stirner and it was a measure of her respect for his ideas that she declined to label herself a follower. 'If the beer bears a resemblance in flavour to other brands' she argued, 'it is due to the similarity of taste in the makers'. ${ }^{27}$ Marsden's egoism did not attract such a wide audience as MacKay's, but as a former member of the Women's Social and Political Union who had broken ranks with Pankhursts in 1911, Marsden established her reputation by engaging in a series of 'daredevil acts of militancy' - 
which included "throwing balls labelled "bomb" through the windows of political meetings'. ${ }^{28}$ And as the editor of The Freewoman, New Freewoman and The Egoist, she communicated a rich diet of Stirnerite ideas to cultural and literary avant gardes on both sides of the Atlantic. In addition to activists like Edward Carpenter and Guy Aldred, contributors to the journals included Rebecca West, James Joyce, D.H. Lawrence and Ezra Pound. A very public dispute with Benjamin Tucker helped establish the authoritativeness of her voice and in The Egoist she not only exposed the gulf between her Stirnerism and the Proudhonian version to which Tucker subscribed, she also developed a clear, if biting, generalised critique of anarchism.

John Mackay regarded himself as an anarchist and in common with a number of individualists active in the late nineteenth-century, he argued that anarchism was a necessarily individualist doctrine which was incompatible with communist ideas. The account he gave of the two doctrines indicate his sense of their irreconcilability. Anarchy, he argued, meant the abolition of the state, of artificial boundaries, the bureaucracy, the military and the judiciary; it meant the freedom of individuals to determine and pursue their own interests, consistent with the equal liberty of all. In anarchy, individuals would be free to live their private lives as they saw fit and to experiment without limit. Anarchy also spelt the end of technical languages - in diplomacy, finance, medicine - openness in communication and the development of free schools. In economics, it was based on the abolition of monopoly, free exchanges of goods and ideas and open access to all natural resources. In anarchy, individuals would receive the full value of their labour and were free to fix its price. Work would be the only source of value and the best goods would be offered for sale at the lowest possible price. Because it was just, Mackay argued, anarchy promised the disappearance of crime and poverty. Mackay believed that communism was an 
altogether different prospect and whether or not it was called anarchist it was, in fact, a celebration of the state.

Communism was the negation of all this. Mackay associated it with the subordination of private interests to the public good, the regimentation of public services (economic planning and the direction of labour, the nationalisation of industry) as well as the regulation of family life, including marriage and reproduction. It offered no scope for freedom of expression or artistic licence and instead required that science, art and learning be governed to satisfy the interests of the state. In The Anarchists, he linked communism with the doctrines of equality first elaborated by Babeuf.$^{29}$ It was not surprising, then, that he echoed Proudhon's description of government to characterise communism as a system of surveillance, examination, spying and control. Communists pictured communism as heaven on earth, but in reality it meant only boredom, restriction and dull uniformity. ${ }^{30}$

One of Mackay's chief worries about communism was that it entailed the close monitoring of private life. As Kennedy notes, it would be 'simplistic to suppose that Mackay's realization that his sexual orientation was irreconcilable with modern society led him to advocate anarchism', but his homosexuality and his promotion of man-boy love influenced his politics, nonetheless. ${ }^{31}$ Thomas Riley, Mackay’s biographer, argues that Mackay's attraction to Stirner was forged by his sense of the brutality of life (he described old age as 'an undignified struggle for every next day without the prospect for improvement' $)^{32}$ - a feeling reinforced by the hardship of being a social outcast and sexual outlaw. ${ }^{33}$ The complexity of his identity overlapped with anarchism in two particular ways. On the one hand, his active campaigning for emancipation made him acutely aware of the social tensions of personal freedom. These tensions, he concluded, could only be mitigated, not resolved. '"Life itself will 
find a solution'", he said. ${ }^{34}$ Whatever the costs, it was better that disputes were left to the process of living than given to the judgements of particular individuals, since the latter could never act flexibly and would always fix the boundaries of acceptable behaviour in repressive codes. On the other hand, Mackay's sense of disadvantage encouraged him to conceptualise freedom in terms of a human capacity to love or to realise what he called 'destiny'.

Mackay's ideal was free love: the 'freedom to "unite in love with any other being to whom he is drawn, if he finds mutual love there, and be allowed to separate from this being at any time, when the attraction no longer exists", ${ }^{35}$ His understanding of this arrangement was not contractual in a narrowly legalistic sense, though free love was based on explicit consent. Love, as Riley notes, meant for Mackay 'the right to satisfy his love longings, and to give love where it was needed (as he felt)'. ${ }^{36}$ In later life Mackay argued: 'Each strives constantly, uniquely, and alone for his own happiness (and then all the more if he believes to find it "in others"'). ${ }^{37}$ This idea of love's drives left space for irrationality, emotional enslavement and exploitation. Mackay depicted precisely this condition in The Hustler, describing the torture that the lovelorn hero Herman experiences as a result of Gunther's juvenile, uncaring, instrumentalism and, ultimately, Gunther's psychological destruction at the point of the relationship's demise. The priority Mackay assigned to love resonated with Oscar Wilde's idea of personality: both argued that individuals should have the latitude to 'be themselves'. ${ }^{38}$ Yet whereas Wilde linked personality to inner peace, using Christ as his model, Mackay associated it with risk and tied its expression to boldness, courage and assertion. He probed this idea in the conclusion to The Hustler, when Hermann attempts to come to terms with the collapse of his affair with the teenager and rises above the public shame of his 
conviction for indecent assault. The female relative who lends him her support tells Hermann that pederasty: 'is your destiny ... Neither oppose it, nor bow down under it. Neither will help you to the only happiness that there is for you. Make a peace treaty with it, and direct it. Then you will conquer it and only in that way'. ${ }^{39}$ She continues: 'Let it be light - your love ... And do not question! ... Since it stands outside of all laws and morals of peoples, it is freer and - perhaps also more beautiful for it'. ${ }^{40}$

The critique of anarcho-communism that Mackay presented in The Anarchists was not a crude attempt to brush it with the tar of communist repression.

Nevertheless, the conclusions he drew from his experiences in London led him to believe that anarcho-communist doctrines would inevitably result in the creation of a repressive and oppressive statist system. Anarcho-communists were not disingenuous, they were deluded; and to show the dangers of the doctrines they espoused Mackay set out to expose their utopianism.

Mackay presented his analysis through two main characters: Conrad Auban and Otto Trupp. Meeting up in London, these former comrades discover that their views have drifted apart: Auban has adopted an individualist position whilst Trupp remains mired in communism. Mackay identified Trupp's view as Bakuninist, but he also associated anarcho-communist utopianism with Kropotkin and William Morris.

Although he was sensitive to the differences between them he argued that they shared a trust in abstract thought and a yearning for ideal community. For example, Bakunin was a romantic idealist. The 'shapeless structure of a general philosophy ...

shimmering with promise' underpinned his 'ideal of brotherly love' and it wrongly led him to the conviction that the reality matched with 'sufficient clearness what he aspires after'. ${ }^{41}$ Kropotkin 'had attempted to lay down the "scientific foundations" of his ideal' and, unable to see the 'delusive faith' he placed in them, was also unable to 
foresee the 'evil harvest of despotism, confusion and ... intense misery' they would reap. ${ }^{42}$ Morris spoke as a poet rather than a scientist and his communism was built on hope: "'How beautiful it would be if it could be so - how everything would be dissolved in harmony and peace"”. Auban believed such hope ran against reason and called it 'something evil'. ${ }^{43}$ Thinking through him, Mackay summed up Morris's 'picture of the free society' as 'enticingly and delusively' fictional as Bakunin's or Kropotkin's. ${ }^{44}$ None of them were able to grasp reality and all of them consequently believed that the elaborate fiction of harmony and fellowship they identified with anarchy was not only possible but that it ought to be put into practice. This is the charge that Auban puts to Trupp:

... you have forced an ideal of a future of happiness which corresponds most nearly to your own inclinations, wishes, habits. By naming it "the ideal of humanity" you are convinced that every "real and true man" must be just as happy under it as you. You would fain make your ideal the idea of all.... I on the contrary, want liberty which will enable each to live according to his ideas. I want to be let alone, I want to be spared from any demands that may be made in the name of "the ideal of humanity". 45

Mackay identified the principle of community that lay at the heart of communism as a religious idea: it demanded faith in the possibility of a future transformation - akin to the promise of life after death; obedience to those who were able to picture the vision of earthly paradise; and, above all, a duty to sacrifice all in the pursuit of the cause. ${ }^{46}$ Nechaev was the archetypal communist revolutionary and Trupp was made in his mould. Mackay described Trupp as someone who had learned 
'by heart, those mad eleven principles "concerning the duties of the revolutionist to himself and to his fellow-revolutionists," which begins with the frightful worlds of the greatest illiberality: "The revolutionist is a self-immolated person ...". ${ }^{47}$ Like Nechaev, Trupp is a 'fanatic of fantasy" ${ }^{48}$ who extols terrorism as a means of revolutionary struggle because he believes that the particular sacrifices it demands are the noblest test of revolutionary commitment. His conviction points to a separation of the means and ends of revolutionary struggle which Mackay regarded as selfdefeating. '[T]hese people', Auban declares 'make a point of excelling each other in sacrifices and of seeking their pride not in victory, but in defeat! Sacrifice upon sacrifice!'. ${ }^{49}$ Yet Mackay did not identify the flaw of communist-anarchism in its utilitarianism alone. Anarchist-communist religiosity had an emotional dimension: Trupp and his ilk were sentimentalists who pitied the needy and oppressed. ${ }^{50}$ This theme also emerged in The Hustler: Mackay described Herman's pity for Gunther's impoverishment as 'that most dangerous of all matchmakers of love'. ${ }^{51}$ Just as Herman's sentiments confuse him, blinding him to the physical basis of his attraction, in The Anarchists Trupp's sense of injustice leads him to believe, wrongly, that his duty is to others, rather than to himself. He thinks that he is responsible for delivering the downtrodden from their misery. As Mackay puts it: Trupp 'had lost himself more and more in the generality of mankind ... had placed himself at the service of his cause and felt as belonging to it in life and in death'. ${ }^{52}$ Trupp's compassion is a measure of the degree to which he has become a slave to his fantastic ideal, and whilst it leads him to justify the most outrageous violence and to give himself up in service to the oppressed, Auban is more disturbed to see that his pity justifies the imposition of similar obligations on others. For Mackay this position was untenable and he illustrated the perversity of Trupp's thinking in a discussion of the Haymarket 
martyrs, where his subservience to the cause leads him to support the judicial murder of the convicted men and to reject their petition for a pardon as treachery. ${ }^{53}$ Shortly after this episode, Auban tells Trupp:

Continue to throw your bombs, and continue to suffer hanging for it, if you will never grow wise. I am the last to deny the suicide the right of destroying himself. But you preach your policy as a duty toward mankind, while you do not exemplify it in your lives. It is that against which I protest. You assume a tremendous responsibility: the responsibility for the life of others. ${ }^{54}$

In the end, Mackay argued, the contradictions of the anarchist-communist position were impossible for any human to bear. For all his revolutionary zeal, Trupp calls on others to fulfil the duty that he believes to be incumbent on him because he cannot tolerate the harms that his cause requires him to commit. His compassion and pity were real, but they lead him to lose touch with his sense of justice. He goes mad. Auban observes:

Firery, enthusiastic, devoted, he lived only for the cause. He could have given his life for it, and he found no other way than that of a "deed". He had been influenced by passionate speeches and inspiring promises. But his nature shrank from violence and bloodshed, revolted. And in the long struggle between what seemed to him as his holiest duty and that nature which made its fulfilment an impossibility, his mind gave way. ${ }^{55}$ 
Whilst Mackay dedicated The Anarchists to his friend Benjamin Tucker and believed that there was an affinity between his egoism and Tucker's individualism, Dora Marsden elaborated her ideas precisely in order to distinguish her position from Tucker's. Marsden's argument with Tucker erupted some thirty years after Mackay outlined his critique of anarcho-communism and it coincided with the appearance of the London edition of The Ego and Its Own in 1912. The row was provoked by an article Tucker published about Proudhon and the role that contract might play in a future anarchist society. Under Stirner's influence, Tucker had abandoned his theoretical commitment to natural rights, thrown out all notion of 'duty' and adopted in its place a theory of social convention. ${ }^{56}$ Yet prompted by the distortion of Proudhon's work at the hands of Leon Daudet and the French neo-royalists of the Cercle Proudhon, Tucker was keen to show that Proudhon's critique of Rousseau's social contract was not tantamount to the rejection of contract - certainly not in favour of monarchic oaths of allegiance. ${ }^{57}$ In this, he argued that there was indeed a role for contract and quoted approvingly from Proudhon's General Idea of the Revolution in the Nineteenth Century:

The law is clear, the sanction still more so. Three articles, which make but one that is the whole social contract. Instead of making oath to God and his prince, the citizen swears upon his conscience, before his brothers, and before Humanity. Between these two oaths there is the same difference as between slavery and liberty, faith and science, courts and justice, usury and labour, government and economy, non-existence and being, God and man. ${ }^{58}$

Endorsing Proudhon's argument, Tucker added the following rider: 
Leaving out the words "good," "wicked, " "brute," and "Humanity," which are mere surplusage here, this extract, I think, would have been acceptable even to Max Stirner as a charter for his "Union of the Free," - an appreciation of the importance of which is necessary to a complete appreciation of Stirner's political philosophy. If Miss Marsden knows of any idea originating in America, or developed there, of greater moment or larger dimensions than that presented in this page from France, she will do me a very great service in pointing it out. ${ }^{59}$

Tucker's invitation only attracted Marsden's scorn. She replied:

When therefore Mr. Benj. R. Tucker challenges us ... to find him an idea born in America bigger than Proudhon's outlined Social Contract, we are inclined to give it up. It is a thing difficult to accomplish ... It is, in fact, a very dragon, big and very impossible in everything except words. If we outlined a scheme for building a block of flats as high as St. Paul's with lily-stalks for materials, and carefully went into the joys of living therein, and assessed the penalty for occupants who damaged the joinery, may we say, we should consider we were doing something very similar to that which Proudhon does in outlining the social contract. It need not be asserted in the pages of THE NEW

FREEWOMAN that we consider Proudhon was a blazing light in a dark age, but the passage quoted by Mr. Tucker, we think, shows him at his worst. ${ }^{60}$

Marsden's comments are sometimes interpreted as a straightforward rejection of contract. ${ }^{61}$ However, although she believed that contracts were only made to be broken, (in The Egoist she argued that 'it is as natural to make contacts ... as it is for men to laugh, talk and sigh or dogs to bark'), her position was more nuanced. ${ }^{62}$ In

Comment [s3]: Should this be $<$ break $>$ ? No - she's trying to point up the futility of contract through the persistence of the habit - individuals seduced by the concept 
part, as Tucker realised, her concern was not with the substance of Proudhon's claim but the form of its expression. To be seduced, as Tucker had been, by 'the theatricality of Proudhon's style', 'with its faked matter and pompous manner ... [o]ne would have to imagine oneself Cromwell refusing the crown', she mocked. ${ }^{63}$ In the other part, Marsden questioned the assumptions that underpinned Proudhon's position. The reference to 'lily-stalks', she explained, was designed to point out the fiction of his conception of human nature. The 'kind of people he describes never walked on earth: ... they were unreal: figures with no genuine insides, stuffed out with tracts from the Church of Humanity and the Ethical Society'. ${ }^{64}$

Both aspects of Marden's critique were central to her rejection of anarchism and explained her willingness to accept Tucker's designation of her view as 'archist'. She generalised it by advancing two principle claims. The first was that anarchists failed to acknowledge the partiality of their politics. Anarchism was merely an 'interest' and like all others it was locked in a competitive struggle for power. Its success hinged on the anarchists' ability to excite popular passions, lure and encourage others to 'desert their own greyer interests' for the 'throb, the colour, the vividness' of the alternative. ${ }^{65}$ This attack was similar to Mackay's but whereas he pinpointed the particular dangers of anarchist-communism in its irrational, utopian appeals, Marsden was more concerned to expose its generic failures. Her general critique of political movements predated her spat with Tucker. It was the "Woman Movement"” that first drew her fire and led her to conclude that political causes typically dominated their members, breeding passivity and stultification. In The New Freewoman, she argued:

... the individual must give her energy to the cause. Propaganda started to teach women what they owed to the "Cause": the "duty" of draining their stream of 
energy into the dam: to "concentrate" on the idea: to sink individual differences; to do just those things which makes the intelligent stupid. The blight of the "leader" has brought the "movement" to a standstill. The "Women's Movement" is the "Women's Halt". 66

Marsden did not dismiss the anarchists' formal rejection of hierarchy and was not insensitive to the differences between anarchism and other political ideologies but argued that the weakness of political movements applied equally to the anarchists as any other. In politics, she argued, movements typically drew on moral sentiments in the furtherance of their causes. Each "new "leader" has his "precept" for the guidance of the faithful: the "pattern" according to which they must work' ${ }^{67}$ Even without leaders, the anarchists did not depart from this model.

The second strand of her critique was that the anarchists confused human with humane behaviours and by inscribing the former with qualities associated with the latter demanded that individuals love, sympathise and support each other as a condition for social interaction. Anarchists were not alone in this: other socialists and humanitarians made the same mistake and she dubbed them all 'embargoists': they 'endeavour to lay the weight of their "ought" across other people's fads, and endeavour to inhibit them by an appeal to the conscience'. ${ }^{68}$ Against this, Marsden argued that individuals had drives or instincts - what she sometimes called spirit or soul - and that the free society was one in which these were simply given free reign. Her position was similar to Mackay’s but she diverged from him both in her characterisation of these drives and her anticipation of the ways in which they played out in the social realm. Specifically, where he identified love as a central drive, Marsden saw only motion. Her view had a Hobbesian tinge: individuals were moved 
by particular tastes and were able to realise their desires by the exercise of will.

Bargains with others depended on individuals' competence (to employ, for example, 'fraud, deception, misrepresentation, bounce, swagger, "honest" miscalculation'); and 'rights' attached to promises were enforced only by might. ${ }^{69}$ Although she rejected the idea that individuals were pleasure-seekers (on the grounds that 'pleasure' was too vague to define), she nevertheless defined behaviours as hedonistic. This allowed her to imagine the possibility of other-regarding behaviours whilst maintaining that the only relevant distinction between actions was the ease or hardship with which they were undertaken: to " "please" oneself is to set one's energies moving in a channel in which they run readily and with comfort ... to sacrifice oneself is to set them on enterprises where they move reluctantly and with hardship' ${ }^{70}$ However, the construction of Marsden's theory was certainly not Hobbesian. Whereas he elaborated his concept of man in a fictional state of nature, she situated the ego in the socialised state. The change of context was significant because instead of conceptualising nature in the abstract, she assumed that individual interests supported social interactions. Her concern was to highlight the ways in which these interactions became habituated, how custom gave way to culture and civilisation to stifle the ego - reversing the relationship between anarchy and order that Hobbes presented.

Like Mackay, Marsden concluded that order was the norm to which most individuals subscribed and that woolly anarchist (for him, anarcho-communist) concepts of care and mutual support provided platforms for a repression as severe as Hobbes's, differing only in the means of regulation it employed. Yet reserving no special place for love in the measurement of freedom, Marsden identified the assertion of will as its only instrument. The American rebels of the 1770 s were one model: 'no large servant class amongst them [t]hey came from a picked stock; self- 
assertive and powerful; too powerful to brook control' ${ }^{71}$ Emptying hedonism of content, she also jettisoned the basic equality that Mackay's conception of the ego assumed. Not everyone, she argued, had the 'genius and charm' to assert their interests. ${ }^{72}$ Some were too stupid or supine - the crowd - and others were insufficiently wilful and rightly suffered the herd's strictures. Her reasoning resulted in some startling judgements. For example, she was reasonably favourably disposed to syndicalism. Describing the syndicalist as 'an anarchist crossed with a mild egoist strain', she characterised the willingness to engage in sabotage as a sign of selfassertion:

In "sabotage," or in the conception of the general strike, there is a faint realisation that to win large shares in the world's spoils working men must be ready to string their hearts and consciences up to the pitch of being despoilers. To hold one's own purposes so much in esteem as to be prepared to push others to the rear in their interest is a first sign of power. ${ }^{73}$

Equally surprising was her assessment of Oscar Wilde. Now celebrated for his defiant transgression, Marsden judged him as insufficiently egoistical. 'For a dazzling intelligence to suffer itself to be shamed to death by the rabble', she noted, 'is a shocking and offensive thing'. Nevertheless, Wilde only had himself to blame: 'a brilliantly audacious and adventurous life, only half-self-conscious, and consequently only half-expressed, must of its very nature invite it'. ${ }^{74}$

In the period she edited The Egoist, Marsden's thought evolved from 'literal to linguistic' rebellion and she became increasingly preoccupied with the restrictions of language. ${ }^{75}$ Words, she argued, had 'grown into masters of all and servant of none', 
their 'origins lost through the great multitude of their begetters'. Used without precision, language had become stupefying, 'a magic mesh which neither screens nor lights up the mind'. By their repeated, careless use of particular words - 'liberty', 'equality', 'fraternity', for example - generations of philosophers had invested some words with special mystery or 'prestige'. Their words 'have grown great and climbed high to secure all the heavenly seats'. No matter how critically it was applied, inherited language only commanded, tyrannised and enslaved. Marsden continued: "'In the beginning was the Word, and the Word was God," they will say.' The point, however, was to 'blast the Word, and reduce it to its function of instrument'. Only this would bring 'the enfranchisement of the human kind: the imminent new assertion of its next reach in power'. 76

Marsden acknowledged that anarchist politics represented a break with existing social arrangements, but the change it promised was quite different from the one she looked for and it took the form of a substitution rather than a transformation. The precept of the anarchists - or clerico-libertarians as she called them - was liberty and respect for the liberty of others. ${ }^{77}$ Their aim was to eradicate class difference and the system of benevolent charity that it supported, but in achieving this, the anarchists would only institutionalise a principle of mutual support in liberty's name. Just another form of 'embargoism', anarchism threatened to smother individuals in a regime of moral rules, rituals and taboos, inculcated through language, culture and tradition just as all previous embargos had done. Anarchism appeared to be radical but, she argued, this was just an illusion:

Opposition to the "State" because it is the "State" is futile: a negative, unending fruitless labour. "What I want is my state: if I am not able to establish that, it is 
not my concern whose State is established: my business was and still remains the establishing of my own. The world should be moulded to my desire if I could so mould it: failing in that, I am not to imagine that there is to be no world at all: others more powerful than I will see to that. ${ }^{78}$

\section{Egoism and the politics of anarchism}

The undeniably rich interpretations of Stirner that Mackay and Marsden offer are deeply provocative, but their critiques differ in important respects. As a subscriber to The Freewoman and The New Freewoman, Mackay would have been familiar with Marsden's work, though his correspondence with Tucker gives no indication of his assessment. Whilst he also attempted to subscribe to The Egoist, the issues seem never to have been delivered. ${ }^{79}$ As Tucker's friend, it is likely that Mackay would have been unsympathetic to the tone of Marden's critique, but there were in any case significant differences between them. Although many of the themes Marsden explored were common to Mackay these differences affected the way in which they conceptualised egoism, their understandings of egoist union and their perceptions of anarchism's shortcomings.

At the centre of Mackay's egoism is a concept of man that is comparable to liberal thought. In the public sphere, man is a right-bearer and self-owner, with a sense of justice and a capacity to reason. Thus, Auban jettisons the romanticism that enslaves Trupp, but retains a legitimate 'faith in the slowly, slowly acting power of reason, which will finally lead every man, instead of providing for others, to provide for himself' ${ }^{80}$ Having freed himself from socialism - 'the last general stupidity of mankind" ${ }^{81}$ - he realises that 'justice ... has become the only rightful guide and 
director in our lives' ${ }^{82}$ His negative freedom requires only that the artificial barriers of state and monopoly are removed for justice to be realised. Admittedly, in the private sphere, the realisation of freedom is complicated by love's drives. Here freedom has a positive character and it speaks to concepts of self-realisation, tyranny and conquest. Mackay was under no illusions about the costs of this form of freedom but it was Marsden who put the point most powerfully. The illusion of love, she noted, was that 'one seems to desire not one's own interests but another's'. In reality 'the lover is a tyrant kept within bounds by the salutary fear that the substance of his desire will slip from his grasp: whereas his paramount interest is to retain his hold on it'. $^{83}$

From Marden's perspective Mackay's ideal of liberal freedom drew him closer to the clerico-libertarian position than she could countenance. Veering towards existentialism, she treated the ego as a plain fact - a mere 'unit of life' - and rejected all notions that it described a moral category. ${ }^{84}$ The statements 'I am', 'I feel', 'I live', 'I sense', 'I exist', she argued, were all instances of 'an assertion made twice'. The "'I", she continued, "is the comprehensive expression of existence as viewed by the only unit competent to view it: the one who exists'. ${ }^{85}$ As Bruce Clarke argues, her view was that the ego was not 'referable, is not to be referred to any idea, emphatically not to Statist ideas. Rather, for their worth ideas are to be referred to selves and their several purposes' ${ }^{86}$

The differences resulted in two alternative conceptions of anarchist or archist union. For both, egoism justified narrowly self-centred behaviour, enabling individuals to take what they could from others in the fulfilment of desire. But Mackay identified anarchy as a condition in which mutual independence was supported by conventions designed to empower individuals, where the strong were no 
longer told to "“Become weak!"” but the weak were exhorted to "“Become strong!", 87 Archy provided space for custom, but Marsden defined this as 'habitual conduct' to which 'public opinion attaches small weight either by way of approval or disapproval' contrasting it to morality, which she dismissed as custom backed by authority. ${ }^{88}$ Rather than seeing property as a right or a guarantee of independence, she saw it merely as “"one's own”", a principle of mastership limited only by the will. ${ }^{89}$ Mackay's ideal was sensual and egalitarian. Archy was combative and the continuous transgression Marsden embraced assumed a moral orthodoxy against which to transgress.

Mackay and Marsden offered different diagnoses of anarchist failure. Mackay identified the communists' error in pity. Their sentimental reaction to injustice placed them in a protective relationship with the disadvantaged and misled them into supposing that compassion was a natural human response to suffering and, therefore, that it provided a moral foundation for a self-regulating society - a belief he characterised as utopian. Marsden's view was similar, though she seemed unsure whether the anarchists were deluded or fraudulent: either they were too stupid to see that human actions were always self-regarding or they were Machiavellian and elevated ideas of altruism and sacrifice as a political ruse. In any case, their doctrine was just another ideological barrier to the assertive ego. However, whereas Mackay's worry was that individuals would be unable to pattern their behaviours in the ways that anarcho-communists desired without the use of force, her concern was that they were all too malleable and could be endlessly patterned. Similarly, whilst Mackay criticised anarcho-communists for subordinating reason to passion and identified the danger of sentiments with ruinous protest, Marsden accused the anarchists of stifling the ego's dynamic, vital energy and saw in morality only disciplining power. 
The Stirnerism of both Mackay and Marsden dovetails with Newman's in a number of areas. All share the suspicion of utopianism, the rejection of causes and the celebration of difference, autonomy and inventiveness. Yet neither version of egoism maps neatly onto his account; the mirror they hold up to anarchism reflects a different image from the one he finds. Newman rightly sets Stirner's thought in the context of a debate about Hegelianism and traces a counter-dialectic to contest a concept of evolution in which individuals (citizens or comrades) overcome their alienation to realise themselves in ethical union. ${ }^{90}$ In contrast, Mackay and Marsden are inspired by Tucker and Proudhonian mutualism and use this as the springboard for their critiques. As Riley notes, philosophical interpretations of Stirner's Young Heglianism drew nothing from Mackay and he, in turn, took from The Ego and Its Own 'only what he desired, not what others told him was there'. ${ }^{91}$ His and Marsden's complaint was not that anarchist theory was based on an abstract conception of the citizen/comrade, but that the adoption of socialist doctrines squeezed out and conditioned the space for self-assertion. The conclusion is similar, but for Mackay and Marsden, the litmus test of anarchist failure was the elevation of conscience and the demand for compassion or - in Marsden's case - public concern or interest in others, not the denial of difference.

How far either Mackay or Marsden faithfully interpreted Stirner is a moot point. Riley suggests that Mackay's was a more unsocial doctrine than Stirner ever propounded. ${ }^{92}$ Steven Lukes's sketch of Stirner closes the gap. Stirner, he argues, took the 'German idea of individuality ... as a cult of individual genius and originality ... stressing the conflict between individual and society and the supreme value of subjectivity' and turned it into 'an uninhibited quest for eccentricity and ... the purist egoism and social nihilism'. ${ }^{93}$ However the relationship between Stirner, Mackay and Marsden is understood, Lukes's view perfectly captures the gap between them and 
Newman. This difference is instructive because it allows greater scope for dialogue between anarchists than Newman's Stirnerism suggests. For example, it is possible to accept Mackay's and Marsden's anxieties about the domination of causes whilst challenging their rejection of promising and conscience. Likewise, it is possible to embrace the egoist celebration of experimentation and self-expression without endorsing egotistical behaviours, as Marsden and Mackay allow. To reject hedonism on Marsden's model in favour of sociability is not to call for uniformity, but a challenge to her defence of might as the only measure of right and her idea that conscience is a weakness which 'shrinks' as the ego becomes 'more powerful and more aware'. ${ }^{94}$ Mackay's rejection of pity as dangerously utopian is also too stark in the choice it presents and fails adequately to distinguish between love for intimates and compassion for strangers. As Antliff suggests, the spaces that turn-of-the-century anarchists and anarcho-communists occupied in their engagement with individualism still exist. Their rediscovery requires that the mirror Stirner holds up to anarchism reflects both ways.

\section{References}

Antliff A. (2007) Anarchy, Power and Poststructuralism Sub-stance Issue 113 vol. 36 no. 2 .

Baginksi M. (1907) 'Stirner: "The Ego and His Own”' Mother Earth vol. II no. 3 http://www.nonserviam.com/egoistarchive/commentaries/Baginski_Max.html (accessed 11 November 2010).

Blackledge P. (2011) 'The Struggle for Freedom and Democracy: Marxism, Anarchism and the Problem of Human Nature' in D. Berry, R. Kinna, S.Pinta 
and A. Prichard (eds) Libertarian socialism: Politics in Black and Red, (Basingstoke: Palgrave Macmillan) forthcoming.

Clarke B. (1996) Dora Marsden And Early Modernism: Gender, Individaulism, Science (Ann Arbor: University of Michigan Press).

Delap L. (2007) The Feminist Avant-Garde: Transatlantic Encounters of the Early Twentieth Century (Cambridge: Cambridge University Press).

Fleishmann E. (1971) 'The Role of the Individual in Pre-Revolutionary Society: Stirner, Marx and Hegel' in Z. Pelczynksi Hegel's Political Philosophy (Cambridge: Cambridge University Press).

Garner L. (1990) A Brave and Beautiful Spirit: Dora Marsden 1882-1960 (Aldershot: Avebury Gower Publishing).

Kennedy H. (1983) Anarchist of Love: The Secret Life of John Henry Mackay (New York: Mackay Society).

Kennedy H. (2002) Afterword to The Hustler: The Story of A Nameless Love from Friedrichstrasse (Xlibris Corporation).

Kropotkin, P. (1970) ‘Anarchism’ in R.N. Baldwin (ed.) Kropotkin's Revolutionary Pamphlets (New York: Dover), pp. 284-300.

Lukes, S. (1990) Individualism (Oxford: Blackwell).

Mackay J.H. (n.d.).'Communisme ou Individualisme Anarchiste' (extract) in E. Armand ed. Les Différents Visages de L'Anarchisme (Paris and Orléans: Editions de l'en dehors).

Mackay J.H. (1891) The Anarchists: A Picture of Civilization at the Close of the Nineteenth Century trans. Georg Schumm (Boston Mass.: Benj. R. Tucker). Mackay J.H. (2000) Autobiographical Writings trans. and ed. H. Kennedy (Xlibris Corporation). 
Mackay J.H. (2002) [1926] The Hustler: The Story of A Nameless Love from

Friedrichstrasse trans. H. Kennedy (Xlibris Corporation).

Marsden D. (1914-17) The Egoist (London)

Martin J. (1970) Men Against the State: The Expositors of Individualist Anarchism in America 1827-1908 (Colorado Springs: Ralph Myles Publisher Inc.).

McElroy W. (2003) The Debates of Liberty: An Overview of Individualist Anarchism, 1881-1908 (Lanham, Md.: Rowman and Littlefield).

Nettlau M. (2000) ‘Anarchism: Communist or Individualist?’ in P. Glassgold (ed.) Anarchy! An Anthology of Emma Goldman's Mother Earth (New York: Counterpoint).

Newman S. (2005) Power and Politics in Poststructuralist Thought (London and New York: Routledge).

Parker S.E. (1986) 'The New Freewoman: Dora Marsden \& Benjamin R. Tucker’ in M. Coughlin, C. Hamilton and M. Sullivan (eds) Benjamin R. Tucker And The Champions of Liberty: A Centenary Anthology (St. Paul and New York: Coughlin \& Sullivan Publishers).

Riley T. (1972) Germany's Poet-Anarchist John Henry Mackay: A Contribution to the History of German Literature at the Turn of the Century (New York: The Revisionist Press).

Schmidt M. \& van der Walt L. (2009) Black Flame: The Revolutionary Class Politics of Anarchism and Syndicalism vol. 1 Counter-Power (Edinburgh and Oakland Ca.: AK Press).

Skirda A. (2002) Facing the Enemy (Edinburgh and Oakland Ca.: AK Press). 
The New Freewoman - An Individualist Review (London)

http://www.nonserviam.com/egoistarchive/marsden/TuckerByingtonIndex.ht $\underline{\mathrm{ml}}$ accessed 10 November 2010.

Wilde O. (1912) The Soul of Man Under Socialism (London: Arthur J. Humphreys).

\footnotetext{
${ }^{1}$ I am grateful to participants at the Anarchism panel of the 2010 Manchester Workshops in Political Theory and to Sureyyya Evren and Saul Newman for comments on this paper.

${ }^{2}$ Max Nettlau (2000) 'Anarchism: Communist or Individualist?' in P. Glassgold (ed.) Anarchy! An Anthology of Emma Goldman's Mother Earth (New York:

Counterpoint), pp.79-83.

${ }^{3}$ Max Baginksi M. (1907) 'Stirner: "The Ego and His Own"” Mother Earth vol. II no.3 http://www.nonserviam.com/egoistarchive/commentaries/Baginski_Max.html (accessed 11 November 2010), p.142.

${ }^{4}$ Paul Blackledge, (2011) 'The Struggle for Freedom and Democracy: Marxism, Anarchism and the Problem of Human Nature' in D. Berry, R. Kinna, S.Pinta and A. Prichard (eds) Libertarian socialism: Politics in Black and Red, (Basingstoke: Palgrave Macmillan) forthcoming.

${ }^{5}$ Skirda A. (2002) Facing the Enemy (Edinburgh and Oakland Ca.: AK Press), pp.101-3.

${ }^{6}$ Schmidt M. \& van der Walt L. (2009) Black Flame: The Revolutionary Class Politics of Anarchism and Syndicalism vol. 1 Counter-Power (Edinburgh and Oakland Ca.: AK Press), p.67.

${ }^{7}$ Saul Newman (2005) Power and Politics in Poststructuralist Thought (London and New York: Routledge), p.30.

${ }^{8}$ Antliff A. (2007) 'Anarchy, Power and Poststructuralism' Sub-stance Issue 113 vol. 36 no. 2: 56-66.

${ }^{9}$ Newman, Power and Politics in Poststructuralist Thought, p.19.

${ }^{10}$ Newman, Power and Politics in Poststructuralist Thought, p.21.

${ }^{11}$ Newman, Power and Politics in Poststructuralist Thought, p.23.
} 
${ }^{12}$ Newman, Power and Politics in Poststructuralist Thought, p.26.

${ }^{13}$ Newman, Power and Politics in Poststructuralist Thought, pp.27-8.

${ }^{14}$ Newman, Power and Politics in Poststructuralist Thought, p.26.

${ }^{15}$ Newman, Power and Politics in Poststructuralist Thought, p.28.

${ }^{16}$ Newman, Power and Politics in Poststructuralist Thought, p.29.

${ }^{17}$ Newman, Power and Politics in Poststructuralist Thought, p.29.

${ }^{18}$ Newman, Power and Politics in Poststructuralist Thought, p.16.

${ }^{19}$ Newman, Power and Politics in Poststructuralist Thought, p.17.

${ }^{20}$ Newman, Power and Politics in Poststructuralist Thought, p.19.

${ }^{21}$ Newman, Power and Politics in Poststructuralist Thought, p.23.

${ }^{22}$ Newman, Power and Politics in Poststructuralist Thought, p.19.

${ }^{23}$ Hubert Kennedy (2002) Afterword to The Hustler: The Story of A Nameless Love from Friedrichstrasse (Xlibris Corporation), p 296.

${ }^{24}$ Hubert Kennedy (1983) Anarchist of Love: The Secret Life of John Henry Mackay (New York: Mackay Society), p.16.

${ }^{25}$ Peter Kropotkin (1970) 'Anarchism' in R.N. Baldwin (ed.) Kropotkin's

Revolutionary Pamphlets, (New York: Dover), p.292.

${ }^{26}$ John Henry Mackay (2000) Autobiographical Writings trans. and ed. H. Kennedy

(Xlibris Corporation), p.52.

${ }^{27}$ Dora Marsden The Egoist 15 Jan. 1914, p.24a

${ }^{28}$ Lucy Delap (2007) The Feminist Avant-Garde: Transatlantic Encounters of the Early Twentieth Century (Cambridge: Cambridge University Press), pp.22-3.

${ }^{29}$ John Henry Mackay (1891) The Anarchists: A Picture of Civilization at the Close of the Nineteenth Century trans. Georg Schumm (Boston Mass.: Benj. R. Tucker), p.134.

${ }^{30}$ John Henry Mackay (n.d.).'Communisme ou Individualisme Anarchiste' (extract) in E. Armand ed. Les Différents Visages de L'Anarchisme (Paris and Orléans:

Editions de l'en dehors), pp.40-7.

${ }^{31}$ Kennedy Anarchist of Love, p. 12.

${ }^{32}$ Mackay Autobiographical Writings, p.101.

${ }^{33}$ Thomas Riley (1972) Germany's Poet-Anarchist John Henry Mackay: A

Contribution to the History of German Literature at the Turn of the Century (New

York: The Revisionist Press), p.125.

${ }^{34}$ Kennedy Anarchist of Love, p.13.

${ }^{35}$ Kennedy Anarchist of Love, p.19.

${ }^{36}$ Riley Germany's Poet-Anarchist John Henry Mackay, p.75.

${ }^{37}$ Mackay Autobiographical Writings, p.103.

${ }^{38}$ Oscar Wilde (1912) The Soul of Man Under Socialism (London: Arthur J.

Humphreys), p.24.

${ }^{39}$ John Henry Mackay (2002) [1926] The Hustler: The Story of A Nameless Love from Friedrichstrasse trans. H. Kennedy (Xlibris Corporation), p.291.

${ }^{40}$ Mackay The Hustler, pp.291-2.

${ }^{41}$ Mackay The Anarchists, p.79.

${ }^{42}$ Mackay The Anarchists, p.46.

${ }^{43}$ Mackay The Anarchists, p.137.

${ }^{44}$ Mackay The Anarchists, p.50.

${ }^{45}$ Mackay The Anarchists, p.139.

${ }^{46}$ Mackay The Anarchists, p.105.

${ }^{47}$ Mackay The Anarchists, p.78. 
${ }^{48}$ Mackay The Anarchists, p.230.

${ }^{49}$ Mackay The Anarchists, p. 217.

${ }^{50}$ Mackay The Anarchists, p.12.

${ }^{51}$ Mackay, The Hustler, p.66.

${ }^{52}$ Mackay The Anarchists, p.111.

${ }^{53}$ Mackay The Anarchists, p.215.

${ }^{54}$ Mackay The Anarchists, pp.253-4.

${ }_{55}^{55}$ Mackay The Anarchists, p.239.

56 James J. Martin (1970) Men Against the State: The Expositors of Individualist Anarchism in America 1827-1908 (Colorado Springs: Ralph Myles Publisher Inc.). pp.251-2; Wendy McElroy (2003) The Debates of Liberty: An Overview of Individualist Anarchism, 1881-1908 (Lanham, Md.: Rowman and Littlefield), p.13

${ }^{57}$ S.E. Parker (1986) 'The New Freewoman: Dora Marsden \& Benjamin R. Tucker' in M. Coughlin, C. Hamilton and M. Sullivan (eds) Benjamin R. Tucker And The

Champions of Liberty: A Centenary Anthology (St. Paul and New York: Coughlin \& Sullivan Publishers), p.151.

${ }^{58}$ Benjamin R. Tucker New Freewoman - An Individualist Review (London) 1 Oct.

1913 http://www.nonserviam.com/egoistarchive/marsden/TuckerByingtonIndex.html (accessed 10 November 2010).

${ }^{59}$ Tucker New Freewoman, 1 Oct. 1913.

${ }^{60}$ Dora Marsden New Freewoman, 15 Oct. 1913.

${ }^{61}$ Les Garner (1990) A Brave and Beautiful Spirit: Dora Marsden 1882-1960

(Aldershot: Avebury Gower Publishing), p.111.

${ }^{62}$ Dora Marsden The Egoist, 15 Jan. 1914, p 25 b.

${ }^{63}$ Marsden The Egoist, 15 Jan. 1914, p.25b.

${ }^{64}$ Marsden The Egoist, 15 Jan. 1914, p.25b.

${ }^{65}$ Marsden The Egoist, 15 Sep. 1914, p.343b.

${ }^{66}$ Marsden New Freewoman, 1 Nov, 1913.

${ }^{67}$ Marsden The Egoist, 2 Mar. 1914, p.82b.

${ }^{68}$ Marsden The Egoist, 1 Sep. 1914, p.325a.

${ }^{69}$ Marsden The Egoist, 1 July 1914, p.242a; 15 Aug. 1914, p.303a.

${ }^{70}$ Marsden The Egoist, 15 Jan. 1914, p.24b.

${ }^{71}$ Marsden The Egoist, 15 July 1914, p.264a.

${ }^{72}$ Marsden The Egoist, 2 March 1914, p.83a.

${ }^{73}$ Marsden The Egoist, 15 Aug. 1914, p.305b.

${ }^{74}$ Marsden The Egoist, 15 July 1914, p.266b.

${ }^{75}$ Bruce Clarke (1996) Dora Marsden And Early Modernism: Gender, Individualism, Science (Ann Arbor: University of Michigan Press), p.201.

${ }^{76}$ Marsden The Egoist, 1 Jan. 1915, p.2ab.

${ }^{77}$ Marsden The Egoist, 2 Mar. 1914, pp.84-5.

${ }^{78}$ Marsden The Egoist, 15 Sep. 1914, p.343b.

${ }^{79}$ Mackay Autobiographical Writings, pp. 207; 209.

${ }^{80}$ Mackay The Anarchists, p. 25.

${ }^{81}$ Mackay The Anarchists, p. 291.

${ }^{82}$ Mackay The Anarchists, p. 48.

${ }^{83}$ Marsden The Egoist, 15 Sep. 1914, p.344b.

${ }^{84}$ Marsden The Egoist, 15 Sep. 1914, p.341a.

${ }^{85}$ Marsden The Egoist, Jan. 1 1915, p.3b.

${ }^{86}$ Clarke Dora Marsden And Early Modernism, p.71 
${ }^{87}$ Mackay The Anarchists, p.290.

${ }^{88}$ Marsden The Egoist, 1 Dec. 1914, p.433a.

${ }^{89}$ Marsden The Egoist, 1 May 1914, p.163a.

${ }^{90}$ Eugene Fleishmann (1971) 'The Role of the Individual in Pre-Revolutionary Society: Stirner, Marx and Hegel' in Z. Pelczynksi Hegel's Political Philosophy (Cambridge: Cambridge University Press), pp.220-29

${ }^{91}$ Riley Germany's Poet-Anarchist John Henry Mackay, p.74.

${ }^{92}$ Riley Germany's Poet-Anarchist John Henry Mackay, p.75.

${ }^{93}$ Steven Lukes, (1990) Individualism (Oxford: Blackwell), p.19

${ }^{94}$ Marsden The Egoist, 1 Aug. 1914, p.283a. 